\title{
Effects of Dietary Supplementation of Some Antioxidants on Liver Antioxidant Status and Plasma Biochemistry Parameters of Heat- Stressed Quail
}

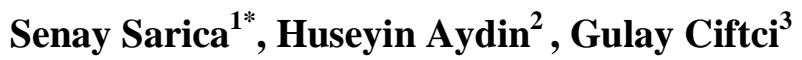 \\ ${ }^{I}$ Department of Animal Science, Faculty of Agriculture, Gaziosmanpasa University, 60240 Tokat, Turkey \\ ${ }^{2}$ Department of Biochemistry, Faculty of Medicine, Cumhuriyet University, 58140 Sivas, Turkey \\ ${ }^{3}$ Department of Biochemistry, Faculty of Veterinary Medicine, University of Ondokuzmayis, 55200 Atakum/Samsun, Turkey
}

\begin{tabular}{l} 
A R T I C L E I N F O \\
Research Article \\
Received 05 February 2017 \\
Accepted 25 April 2017 \\
\hline
\end{tabular}

Keywords:

Antioxidants

Heat stress

Liver

Quail

Plasma biochemistry

\begin{tabular}{l}
${ }^{*}$ Corresponding Author: \\
\hline E-mail: senay.sarica@gop.edu.tr
\end{tabular}

\begin{abstract}
A B S T R A C T
This study aimed to compare the dietary supplementation of oleuropein (O) and $\alpha$-tocopherol acetate (TA) alone or with organic selenium (Se) on liver antioxidant status and some plasma biochemistry parameters in Japanese quails reared under heat stress (HS). A total of 800 , two-weeks old quails were kept in wire cages in the temperaturecontrolled rooms at either $22^{\circ} \mathrm{C}$ or $34^{\circ} \mathrm{C}$ for $8 \mathrm{~h} / \mathrm{d}$ and fed on a basal diet (NC) or the diets supplemented with TA (TA200) or O (O200) at $200 \mathrm{mg} / \mathrm{kg}$ alone or with OSe (TA200+OSe and O200+OSe) to the NC diet. HS decreased the total antioxidant status (TAS) and increased the total oxidative stress (TOS) and oxidative stress index (OSI) of liver compared to thermoneutral temperature (TN). The TA200, O200, TA200+OSe and O200+OSe diets increased TAS and decreased TOS of liver compared to those of quails fed NC. OSI was decreased by the TA200, O200 and TA200+OSe diets compared to NC and $\mathrm{O} 200+\mathrm{OSe}$ diets. HS reduced plasma albumin (A) and total protein (TP) concentrations, on the other hand, increased plasma glucose $(\mathrm{G})$, total cholesterol $(\mathrm{CHO})$ and triglyceride (TG) levels compared to TN. The TA200, O200, TA200+OSe and $\mathrm{O} 200+\mathrm{OSe}$ diets reduced plasma total CHO and TG levels and increased plasma A level. The TA200 and TA200+OSe diets reduced plasma G level and increased plasma TP levels compared to those of quails fed the other diets. In conclusion, dietary supplementation of vitamin $\mathrm{E}$ and oleuropein alone or with organic selenium is necessary to remove the negative effects of heat stress on liver antioxidant status and some plasma parameters of quails.
\end{abstract}

DOI: https://doi.org/10.24925/turjaf.v5i7.773-779.1182

\section{Introduction}

The heat stress (HS) due to the increased industrialization and environmental degradation is a major problem of the poultry sector in the World (Ajakaiye et al., 2010). HS causes an increase in free radicals by starting lipid peroxidation in cell membranes and the release of stress hormones that directly influence glucose and lipid metabolisms as well as protein catabolism (Hosseini-Mansoub et al., 2010; Imik et al., 2013). Increasing concentrations of corticosterone were parallel to increases in serum glucose, triglyceride and cholesterol concentrations (Sahin et al., 2003). There are several methods to alleviate the negative effects of HS of poultry. Since the cooling animal buildings is expensive and impractical, such methods are mostly focused on the dietary manipulation (Tawfeek et al., 2014).

It has been suggested that there is a synergistic relationship between selenium $(\mathrm{Se})$ and vitamin $\mathrm{E}$ for amelioration the negative effects of HS in poultry, because Se dependent glutathione peroxidase (GSHPx) continues the work of vitamin $\mathrm{E}$ by detoxifying hydroperoxides (Surai, 2002). Especially in recent years, the organic Se sources have been widely used as an alternative to the inorganic Se because organic $\mathrm{Se}$ is deposited into the animal tissue more efficiently than inorganic Se (Zdunczyk et al., 2013).

Recently, apart from vitamin E, olive-leaf and oil have been receiving much attention as natural antioxidants (Hayes et al., 2011). Oleuropein is the most prominent and active phenolic compound in dried olive leaves (Olea europaea L.)/g (Benavente-Garcia et al., 2000). Most phenolic compounds in the olive leaf or olive leaf extract have been shown in vitro (Silva et al., 2006) and in vivo (Andreadou et al., 2006; Jemai et al., 2008; RuizGutierrez et al., 2001) antioxidant activity. A previous study showed that olea europaea extracts, oleuropein and hydroxytyrosol were much more effective than butylated 
hydroxytoluene (BHT) or vitamin $\mathrm{E}$ as antioxidant (Aruoma et al., 1998). The ability of the bioactive polyphenolic compounds in the olive leaves extract to act as an antioxidant derived from their standard one-electron reduction potential by either donating hydrogen or electron or breaking the free radical chain reaction and by preventing metal ion chelation (Hayes et al., 2011).

The present study aimed to compare the effects of the dietary supplementation of $\alpha$-tocopherol acetate and oleuropein without or with organic selenium on the total antioxidant status, the total oxidative stress and oxidative stress index of liver and some plasma biochemistry parameters in Japanese quails exposed to HS.

\section{Materials and Methods}

\section{Animal Care and Housing}

A total of 800 one-day old Japanese quail (Coturnix coturnix japonica) chicks of mixed-sex purchased from a commercial hatchery (19 Mayis University Poultry Production and Marketing Plant, Samsun, Turkey) were used in the experiment. The study was conducted in accordance with animal welfare at the Poultry Research Centre of Gaziosmanpasa University.

The chicks were weighed and randomly distributed to the 40 wire cages (20 chicks/cage). Each cage was equipped with nipple drinkers and electrical heating system by thermostats. The poultry research house including of these cages had two identical rooms that can be separated with a door. During the first 2 weeks, rooms were not separated and standard brooding temperatures were applied to both rooms with temperature gradually decreased from $32^{\circ} \mathrm{C}$ to $26^{\circ} \mathrm{C}$ by the end of the second week of age. Quails in each wire cages were randomly assigned to 10 experimental groups, 4 replicates of 20 quails each in a 2 (temperature treatments, TTs) $x 5$ (dietary treatments, DTs) factorial arrangement from 3 to 5 weeks.

At two weeks of age, 5 of 10 experimental groups were subjected to either thermoneutral temperature (TN) or HS treatments and HS room was separated from TN room. Temperatures in the rooms were arranged as follows:

- Thermoneutral temperature room: quails were kept at 24, 22 and $20^{\circ} \mathrm{C}$, at 3,4 and 5 weeks. Relative humidity in this room ranged from 50 to $60 \%$ during the experiment.

- Heat stress treatments room: quails were exposed to $34^{\circ} \mathrm{C}$ for $8 \mathrm{~h} / \mathrm{d}(09: 00$ to $17: 00 \mathrm{~h}$ ) and then (from 17:00 to $09: 00 \mathrm{~h}$ ) to 24,22 and $20^{\circ} \mathrm{C}$ at 3,4 and 5 weeks. Relative humidity ranged from 60 to $70 \%$ from 2 weeks until the end of the study. The experiment was conducted during the autumn 2013. Temperature and humidity were monitored in each room at two locations using a temperature-humidity record system. A fluorescent lighting Schedule of 23 $\mathrm{h}$ light and $1 \mathrm{~h}$ dark was used during the study with an average light intensity of 40 lux.

\section{Diets}

Quails in both temperatures were fed one of 5 different diets in mash form until 5 week of age. The 5 experimental diets were as follows: the basal diet (NC, $240 \mathrm{~g}$ crude protein $/ \mathrm{kg}$ and $12.14 \mathrm{MJ} / \mathrm{kg}$ ) included 0.15 $\mathrm{mg}$ sodium selenite (inorganic Se) $/ \mathrm{kg}$ and $50 \mathrm{mg} \alpha-$ tocopherol acetate (vitamin $\mathrm{E}$ ) $/ \mathrm{kg}$ diet and diets were formulated by supplementing of 2 different antioxidant sources $((\alpha$-tocopherol acetate (vitamin E) or oleuropein (olive leaf extract)) at $200 \mathrm{mg} / \mathrm{kg}$ level without (TA200 and O200) or with organic Se (Sel-Plex) at $0.30 \mathrm{mg} / \mathrm{kg}$ level (TA200+OSe and O200+OSe) to the basal diet. Feed ingredients were ground through a $1 \mathrm{~mm}$ screen in preparation for chemical analysis. Prior to experimental diet formulation, feed ingredients were analysed for their crude protein, ether extract, starch and total sugar according to the methods of the AOAC (2007). All diets were formulated to meet minimum nutrient requirements established by the NRC (1994).

The $\alpha$-tocopherol acetate (TA) was supplied from Kartal Chemistry Ltd. (Izmit, Turkey). Organic Se (OSe) was provided as Sel-Plex ${ }^{\circledR} 2000$ from Alltech Biotechnology Food, Agricultural and Animal Products Company (Bornova, Izmir, Turkey). Vitamin premix and trace mineral premix were provided from TopkimTopkapı Drug Company Ltd. (Istanbul/Turkey).

The olive leaf extract was provided by the Bio-Olive Ltd. Company (Ayvalik, Turkey). And then, the extract was filtered with Whatman No.1 filter paper. The filtrates were carried to a rotary evaporator to remove ethanol under reduced pressure at $38^{\circ} \mathrm{C}, 120 \mathrm{rpm}$. The remaining aqueous solutions were lyophilized at $-50^{\circ} \mathrm{C}, 0.028 \mathrm{mbar}$ and the crude extracts were kept in vacuum bags at $-80^{\circ} \mathrm{C}$ until the use.

\section{Analytical Procedures}

Total phenol content of the olive leaf extract (OLE) and the experimental diets was determined by using Folin-ciocalteu method with a modificaion of Lako et al. (2007). Total phenol content of the olive leaf extract (OLE) and the experimental diets was determined by using Folin-ciocalteu method with a modificaion of Lako et al. (2007). Results were expressed as milligrams of gallic acid equivalents (GAE) per fresh weight. The phenol content of OLE was calculated as $196.81 \pm 2.83$ $\mathrm{mg} / \mathrm{GAEq} / \mathrm{g}$ extract.

The oleuropein (O) content of the OLE and experimental diets was analyzed in the Sciences of Izmir Institute of Technology (Izmir, Turkey). The HPLC analysis was used for the determination of the oleuropein content in the OLE and diets supplemented with oleuropein at different levels. Oleuropein in OLE was identified by comparing its retention times with the corresponding standards. The average amount of oleuropein of OLE was $97.0 \mathrm{mg}$ OLE/g. With attention of oleuropein content of OLE, the OLE was supplemented to supply at the level of $200 \mathrm{mg}$ oleuropein/ $\mathrm{kg}$ diet.

Se concentrations of the experimental diets were analysed using hydride generation atomic fluorescence spectroscopy of an acid digest of the samples according 
the method described by Surai et al. (1996). Se concentrations in the diet samples were calculated from the linear relationship $\left(r^{2}=0.999\right)$ obtained using sodium selenite as a standard.

Vitamin E ( $\alpha$-tocopherol acetate) concentrations in the diets were determined using the HPLC system, after sample saponification with ethanolic $\mathrm{KOH}$ in the presence of pyrogallol (Surai et al., 1996). Se, vitamin E ( $\alpha$ tocopherol acetate) and oleuropein contents of the experimental diets are given in Table 1.

\section{Measurements}

Antioxidant status and oxidative stress parameters of liver: At 35 days of age, a total of 120 quails (twelve quails from each group) were randomly selected, bled from the brachial vein and slaughtered to determine the total antioxidant status (TAS) and the total oxidative stress (TOS) of liver. After slaughtering, the liver samples of quails were dissected, flushed with phosphate buffer at $\mathrm{pH}$ : 7.4 and a sample of homogenate was centrifuged in a fixed angle rotor at $4^{\circ} \mathrm{C}$ for $10 \mathrm{~min}$. at $6000 \mathrm{xg}$ to obtain supernatant for analyses of TAS and TOS. Liver homogenate was stored in a freezer at $-80^{\circ} \mathrm{C}$ further analyses of their TAS and TOS parameters.TAS and TOS levels were determined by using commercial kits (Rel Assay Diagnostic) on an autoanalyzer (Beckman Coulter Synchron LX-20) at the Biochemistry Laboratory, Research and Training Hospital, Faculty of Medicine, Cumhuriyet University.

Measurement of the TAS: The TAS levels of the liver were determined using anautomated measurement method based on bleaching of the characteristic color of a 2,2'azino-bis [3-ethylbenzthiazoline-6-sulfonic acid] (ABTS) radical cation caused by antioxidants (Erel, 2004). The results are expressed in mmol Trolox equivalents/L.

Measurement of the TOS: The TOS levels of the liver were determined using a novel automated measurement method (Erel, 2005). Oxidants present in the sample oxidize the ferrous ion-odianisidine complexes into ferric ions. The oxidation reaction is enhanced by glycerol molecules that are abundantly present in the reaction medium. The ferric ions form a coloured complex with xylenol orange in an acidic medium. Therefore, the colour intensity, measured spectrophotometrically, is related to the total number of oxidant molecules present in the sample. The assay is calibrated with hydrogen peroxide and the results are expressed in terms of micromolar hydrogen peroxide equivalent per liter $\left(\mu \mathrm{mol} \mathrm{H}_{2} \mathrm{O}_{2}\right.$ equiv./L).
Oxidative stress index (OSI): The oxidative stress index (OSI) is the percentage ratio of TOS level to TAS level (Kosecik et al., 2005). For calculation, the resulting micromolar unit of TAS was converted to milimoles per liter, and the OSI value was calculated according to the following formula: OSI (arbitrary unit) $=$ TOS (micromolar hydrogen peroxide equivalent per liter)/TAS (nmol Trolox/L).

Plasma biochemistry parameters: At 35 days of age, the blood samples obtained from a total of 120 quails (twelve quails from each group) slaughtered by severing the jugular vein were collected in test tubes with anticoagulant (EDTA) and centrifuged at $2000 \mathrm{xg}$ for 15 min at $4^{\circ} \mathrm{C}$. After centrifugation, plasma was removed and immediately stored at $-80^{\circ} \mathrm{C}$ to determine some plasma biochemistry parameters. Autoanalyser test kits (Audit Diagnostics, Ireland) were used for determination of albumin, total protein, glucose, triglyceride, total cholesterol as Audit Autoanalyser (Autolab, AMS Srl, The Netherlands) as described by the manufacturers.These plasma biochemistry parameters were determined at the Biochemistry Department, Faculty of Veterinary, Ondokuzmayis University.

\section{Statistical Analysis}

A $2 \times 5$ factorial analysis of the variance with a twoway ANOVA by using the GLM procedure of SPSS statistic package (SPSSWIN, 2007) was applied to data related to liver and plasma parameters with a model including dietary treatments and temperature effects and their interactions. Significant differences between treatment means were separated using Duncan's multiple range test (Duncan, 1955). Data were assumed to be statistically significant when $\mathrm{P}<0.05$. Chi-square analysis was performed for mortality rates.

\section{Results and Discussion}

Total Antioxidant Status, Total Oxidative Stress and Oxidative Stress Index of Liver

The effects of the dietary supplementation of TA or O without or with OSe on the TAS, TOS and OSI of liver of quails exposed to TN and HS were summarized in Table 2 .

As shown in Table 2, HS decreased the TAS $(\mathrm{P}<0.01)$ and increased the TOS $(\mathrm{P}<0.05)$ of liver. In addition, the TA200, O200, TA200+OSe and O200+OSe diets increased the TAS $(\mathrm{P}<0.01)$ and decreased the TOS $(\mathrm{P}<0.05)$ of liver.

Table $1 \mathrm{Se}$, vitamin E ( $\alpha$-tocopherol acetate) and oleuropein contents of the diets

\begin{tabular}{l|ccc}
\hline \multicolumn{1}{c|}{ Diets } & Selenium, $\mathrm{mg} / \mathrm{kg}$ & Oleuropein, $\mathrm{mg} / \mathrm{kg}$ & $\alpha$-tocopherol acetate, $\mathrm{mg} / \mathrm{kg}$ \\
\hline NC & 0.21 & - & 80.93 \\
TA200 & 0.24 & - & 278.64 \\
O200 & 0.22 & 195.72 & 79.72 \\
TA200+OSe & 0.50 & - & 280.14 \\
O200+OSe & 0.48 & 198.02 & 81.16 \\
\hline
\end{tabular}

NC: Diet contained $0.15 \mathrm{mg}$ inorganic Se $/ \mathrm{kg}$ and $50 \mathrm{mg} \alpha$-tocopherol acetate (vitamin E) $/ \mathrm{kg}$, TA200: Diet supplemented with $200 \mathrm{mg} \alpha$-tocopherol acetate/kg to NC diet, O200: Diet supplemented with $200 \mathrm{mg}$ oleuropein (olive leaf extract)/kg to NC diet, TA200+OSe: Diet supplemented with 200 $\mathrm{mg} \alpha$-tocopherol acetate $/ \mathrm{kg}$ and $0.3 \mathrm{mg}$ organic Se $/ \mathrm{kg}$ to NC diet, O200+OSe: Diet supplemented with $200 \mathrm{mg}$ oleuropein $/ \mathrm{kg}$ and $0.3 \mathrm{mg}$ organic $\mathrm{Se} / \mathrm{kg}$ to NC diet. 
Both DTs and TTs influenced OSI of quails $(\mathrm{P}<0.01)$. The NC and O200+OSe diets increased OSI of quails compared to those of quails fed the TA200, O200 and TA200+OSe diets $(\mathrm{P}<0.01)$. In addition to, OSI of quails was increased by HS compared to $\mathrm{TN}(\mathrm{P}<0.01)$. This situation may be derived from the increase of free radical production and the reduction of the antioxidant system due to HS (Jang et al. 2014).

This finding is in agreement with the result of Khan et al. (2013) reported that dietary supplementation of vitamin $\mathrm{E}$ increased TAS and reduced TOS and OSI of serum in broilers compared to the CONT diet. In contrast, Jang et al. (2014) showed that serum TAS of broilers under high temperature was not influenced by dietary vitamin E supplementation compared to the basal diet. In addition, Zdunczyk et al. (2013) indicated that the supplementation of vitamin $\mathrm{E}$ and inorganic selenium in combination did not significantly affect serum TAS of laying hens.

Morever, our results related to the increase of serum TAS level due to $\mathrm{O} 200$ and O200+OSe diets concurs with the findings of Ryzner et al. (2013). They found that the diets containing salvia officinalis essential oil alone or together with inorganic Se significantly enhanced the plasma TAS level of broiler chickens.

In addition, Kara et al. (2014) reported that dietary green tea catechins' addition increased the serum TAS concentration of Japanese quails. On the contrary, Lipiński et al. (2015) pointed out that the chickens fed diet with the polyphenol supplement had higher serum TAS compared to the group fed diet only with vitamin E.

This can be attributed to the accumulation of phenolic compounds indicating antioxidant properties in olive leaf extract in various tissues of chickens when this extract was supplemented to diet continous (Lee et al., 2004). It is assumed that the dietary supplementation of this antioxidant phenolic compound might have been suppressed the oxidative stress (Khan et al., 2011).

\section{Plasma Biochemistry Parameters}

The effects of the dietary supplementation of TA or O alone or with OSe on some plasma biochemistry parameters of quails exposed to $\mathrm{TN}$ and $\mathrm{HS}$ were summarized in Table 3. As shown in Table 3, both DTs and TTs influenced plasma albumin $(\mathrm{P}<0.01)$ and total protein $(\mathrm{P}<0.05)$ levels.

HS reduced plasma albumin level $(\mathrm{P}<0.01)$. This result is not in agreement with the findings of Imik et al. (2013) who reported that there is no differences between broilers exposed to normal heat and heat stress in terms of serum albumin concentration.

The TA200, O200, TA200+OSe and O200+OSe diets increased plasma albumin level of quails compared to that of quails fed the NC diet $(\mathrm{P}<0.01)$. This finding concurs with the result of Seyrek et al. (2004). They pointed out that the dietary vitamin $\mathrm{C}$ supplementation at different levels (150, 250 and $500 \mathrm{mg} / \mathrm{kg}$ L-ascorbic acid) of laying Japanese quails exposed to HS significantly increased serum albumin concentration compared to the NC diet. The increase of serum albumin concentration in our study may be explained by the reduction of synthesis and secretion of corticoid hormones in quails received TA and $\mathrm{O}$ alone or in combination. As a result, the reduction of corticoids levels might have reduced protein catabolism and increased serum albumin concentration (Seyrek et al., 2004).

In addition, El-Damrawy et al. (2013) found that feeding diet containing 1 or $2 \%$ olive leaf powder significantly increased plasma albumin level of chickens. In contrast, a previous study showed that dietary supplementation of lemon peel extract, orange peel extract and curcuma xanthorrhiza essential oil at 200 or $400 \mathrm{mg} / \mathrm{kg}$ level did not significantly affect serum albumin concentration of broilers reared under HS (Akbarian et al. 2014). In addition, Ahmed et al. (2015) indicated that serum albumin level of broilers was significantly decreased by dietary supplementation with $1.5 \mathrm{~g} / \mathrm{kg}$ rosemary leaf compared to the vitamin $\mathrm{E}$ supplemented diet.

Likewise, HS decreased plasma total protein level of quails compared to that of quail reared in $\mathrm{TN}(\mathrm{P}<0.05)$. This result is agreement with the finding of Tawfeek et al. (2014) who reported that HS significantly decreased the serum total protein level of broiler compared with that of broiler exposed to TN. This stiuation may be derived from the reduction at the activities of trypsin and chymotrypsin by a high temperature (Hai et al., 2000). As a result, the digestibility of amino acids is decreased at a high environmental temperature in broilers. On the other hand, Yardibi et al. (2009) found that HS did not significantly decrease serum total protein level in laying hens compared to no heat. The TA200 and TA200+OSe diets in our study increased plasma total protein level of quails compared to those of quails fed the other diets $(P<0.05)$. In the same way, serum total protein level is significantly increased in broilers (Sahin and Kucuk, 2001), Japanese quails (Sahin et al., 2006) and laying hens (Ajakaiye et al., 2010) exposed to HS by dietary supplementation of vitamin E. Dietary vitamin E supplementation increased plasma protein level because vitamin E dramatically decreased blood ACTH and the effects of ACTH on protein catabolism in heat-stressed Japanese quails (Sahin et al. 2003).

As indicated in Table 3, HS increased plasma glucose level in quails compared to TN $(\mathrm{P}<0.01)$. The increasing level of plasma glucose may be derived from an increase in free radicals and the release of ACTH and cortisol hormones that prevent insulin release and stimulate gluconeogenesis due to HS (Ajakaiye et al. 2010). Likewise, Kutlu and Forbes (1993) and Rashidi et al. (2010) found that HS increased plasma glucose level. On the other hand, Tatli Seven et al. (2009) recorded that plasma glucose level was not significantly affected by HS.

DTs influenced plasma glucose level and only TA200 and TA200+OSe diets decreased plasma glucose level in quails $(\mathrm{P}<0.01)$ compared to those of quails fed the other diets. In a same way, Kutlu and Forbes (1993) showed that vitamin $\mathrm{C}$ supplementation markedly reduced blood glucose level in heat-stressed broilers. 
Table 2 The effects of dietary supplementation of TA or $\mathrm{O}$ alone or with organic Se on the total antioxidant status and the total oxidative stress of liver of quails exposed to TN and HS

\begin{tabular}{|c|c|c|c|c|}
\hline DTs & TTs & TAS & TOS & OSI \\
\hline \multirow{2}{*}{$\mathrm{NC}$} & $\mathrm{TN}$ & 2.00 & 3.28 & 0.16 \\
\hline & HS & 1.61 & 4.44 & 0.28 \\
\hline \multirow{2}{*}{ TA200 } & $\mathrm{TN}$ & 2.21 & 2.31 & 0.10 \\
\hline & HS & 1.93 & 3.46 & 0.17 \\
\hline \multirow{2}{*}{ O200 } & $\mathrm{TN}$ & 2.08 & 3.05 & 0.14 \\
\hline & HS & 1.68 & 3.19 & 0.18 \\
\hline \multirow{2}{*}{ TA200+OSe } & $\mathrm{TN}$ & 2.59 & 3.06 & 0.11 \\
\hline & $\mathrm{HS}$ & 1.91 & 3.15 & 0.16 \\
\hline \multirow{2}{*}{$\mathrm{O} 200+\mathrm{OSe}$} & $\mathrm{TN}$ & 2.07 & 2.93 & 0.14 \\
\hline & $\mathrm{HS}$ & 1.74 & 4.52 & 0.25 \\
\hline \multirow{5}{*}{ DTs } & $\mathrm{NC}$ & $1.81^{\mathrm{d}}$ & $3.86^{\mathrm{a}}$ & $0.22^{\mathrm{a}}$ \\
\hline & TA200 & $2.07^{\mathrm{b}}$ & $2.89^{\mathrm{d}}$ & $0.14^{b}$ \\
\hline & $\mathrm{O} 200$ & $1.88^{\mathrm{c}}$ & $3.12^{\mathrm{c}}$ & $0.16^{\mathrm{b}}$ \\
\hline & TA200+OSe & $2.25^{\mathrm{a}}$ & $3.10^{\mathrm{cd}}$ & $0.14^{\mathrm{b}}$ \\
\hline & $\mathrm{O} 200+\mathrm{OSe}$ & $1.91^{\mathrm{c}}$ & $3.72^{\mathrm{b}}$ & $0.20^{\mathrm{a}}$ \\
\hline \multicolumn{5}{|l|}{ SEM } \\
\hline & $\mathrm{TN}^{1}$ & $2.19^{\mathrm{a}}$ & $2.93^{\mathrm{b}}$ & $0.13^{\mathrm{b}}$ \\
\hline TTs & $\mathrm{HS}^{2}$ & $1.77^{\mathrm{b}}$ & $3.75^{\mathrm{a}}$ & $0.21^{\mathrm{a}}$ \\
\hline \multicolumn{5}{|l|}{ SEM } \\
\hline \multicolumn{5}{|l|}{$P$ value } \\
\hline DTs & & ** & $*$ & $* *$ \\
\hline TTs & & $* *$ & $*$ & $* *$ \\
\hline DTs x TTs & & NS & NS & NS \\
\hline
\end{tabular}

${ }^{\mathrm{a}-\mathrm{d}}$ Row means within the different supercripts differ significantly $(* \mathrm{P}<0.05 ; * * \mathrm{P}<0.01)$, SEM: Standard Error of Means; NS= $\mathrm{P}>0.05$, ${ }^{\mathrm{I}} \mathrm{TN}$ : Thermoneutral Temperature; ${ }^{2} \mathrm{HS}$ : Heat Stress; DTs: Dietary Treatments; TTs: Temperature Treatments

Table 3 The effects of dietary supplementation of TA or O alone or with organic Se on some plasma biochemistry parameters of quails reared under TN and HS

\begin{tabular}{|c|c|c|c|c|c|c|}
\hline DTs & TTs & $\begin{array}{l}\text { Albumin } \\
(\mathrm{g} / \mathrm{dl})\end{array}$ & $\begin{array}{l}\text { Total Protein } \\
(\mathrm{g} / \mathrm{dl})\end{array}$ & $\begin{array}{l}\text { Glucose } \\
(\mathrm{mg} / \mathrm{dl})\end{array}$ & $\begin{array}{c}\text { Total Cholesterol } \\
(\mathrm{mg} / \mathrm{dl})\end{array}$ & $\begin{array}{c}\text { Triglyceride } \\
(\mathrm{mg} / \mathrm{dl})\end{array}$ \\
\hline \multirow{2}{*}{$\mathrm{NC}$} & $\mathrm{TN}$ & 1.47 & 3.13 & 325 & 203 & 212 \\
\hline & HS & 1.36 & 2.84 & 354 & 259 & 267 \\
\hline \multirow{2}{*}{ TA200 } & $\mathrm{TN}$ & 2.00 & 3.33 & 294 & 181 & 105 \\
\hline & HS & 1.75 & 3.31 & 320 & 229 & 189 \\
\hline \multirow{2}{*}{ O200 } & $\mathrm{TN}$ & 1.54 & 2.99 & 328 & 217 & 154 \\
\hline & HS & 1.45 & 2.95 & 343 & 223 & 208 \\
\hline \multirow{2}{*}{ TA200+OSe } & $\mathrm{TN}$ & 1.68 & 3.70 & 303 & 154 & 85 \\
\hline & HS & 1.46 & 2.82 & 351 & 193 & 152 \\
\hline \multirow{2}{*}{$\mathrm{O} 200+\mathrm{OSe}$} & TN & 1.50 & 2.83 & 313 & 165 & 169 \\
\hline & HS & 1.42 & 2.57 & 353 & 241 & 195 \\
\hline \multirow{5}{*}{ DTs } & $\mathrm{NC}$ & $1.41^{\mathrm{d}}$ & $2.98^{\mathrm{b}}$ & $340^{\mathrm{a}}$ & $231^{\mathrm{a}}$ & $239^{\mathrm{a}}$ \\
\hline & TA200 & $1.88^{\mathrm{a}}$ & $3.32^{\mathrm{a}}$ & $307^{\mathrm{c}}$ & $205^{\mathrm{c}}$ & $147^{\mathrm{c}}$ \\
\hline & $\mathrm{O} 200$ & $1.49^{\mathrm{c}}$ & $2.97^{\mathrm{b}}$ & $335^{\mathrm{a}}$ & $220^{\mathrm{b}}$ & $181^{\mathrm{b}}$ \\
\hline & TA200+OSe & $1.57^{\mathrm{b}}$ & $3.26^{\mathrm{a}}$ & $327^{\mathrm{b}}$ & $173^{\mathrm{d}}$ & $119^{\mathrm{d}}$ \\
\hline & $\mathrm{O} 200+\mathrm{OSe}$ & $1.46^{\mathrm{c}}$ & $2.70^{\mathrm{c}}$ & $330^{\mathrm{ab}}$ & $203^{c}$ & $182^{\mathrm{b}}$ \\
\hline SEM & & 0.059 & 0.201 & 6.357 & 11.32 & 40.63 \\
\hline \multirow[b]{2}{*}{ TTs } & $\mathrm{TN}^{1}$ & $1.64^{\mathrm{a}}$ & $3.20^{\mathrm{a}}$ & $313^{\mathrm{b}}$ & $184^{\mathrm{b}}$ & $145^{\mathrm{b}}$ \\
\hline & $\mathrm{HS}^{2}$ & $1.48^{\mathrm{b}}$ & $2.90^{\mathrm{b}}$ & $344^{\mathrm{a}}$ & $229^{\mathrm{a}}$ & $202^{\mathrm{a}}$ \\
\hline $\begin{array}{l}\text { SEM } \\
\text { P value }\end{array}$ & & 0.038 & 0.128 & 4.022 & 7.159 & 25.93 \\
\hline DTs & & $* *$ & $*$ & $* *$ & $*$ & $* *$ \\
\hline TTs & & $* *$ & $*$ & $* *$ & $*$ & $* *$ \\
\hline DTs x TTs & & NS & NS & NS & NS & NS \\
\hline
\end{tabular}

${ }^{\mathrm{a}-\mathrm{d}}$ Row means within the different supercripts differ significantly $\left({ }^{*} \mathrm{P}<0.05 ; * * \mathrm{P}<0.01\right)$, SEM: Standard Error of Means; NS= P>0.05, ${ }^{\mathrm{T} N \mathrm{~N}}$ Thermoneutral Temperature; ${ }^{2} \mathrm{HS}$ : Heat Stress; DTs: Dietary Treatments; TTs: Temperature Treatments 
Sahin et al. (2003) reported that dietary vitamin C and E supplementatin dramatically decreased blood glucose level in heat-stressed Japanese quail. This shows that dietary vitamin $\mathrm{E}$ alone or with organic selenium supplementation might have reversed oxidative stressdecreased insulin release by increasing the secretion and/or synthesis of glucocorticoids due to HS (Sahin et al., 2003).

As indicated in Table 3, HS enhanced plasma total cholesterol $(\mathrm{P}<0.05)$ and triglyceride $(\mathrm{P}<0.01)$ levels in quails compared to that of quails exposed to TN. Our results related to plasma cholesterol and triglyceride levels are in agreement with the findings of HosseiniMansoub et al. (2010) and Tawfeek et al. (2014). They reported that the serum cholesterol and triglyceride levels in broilers were significantly increased by HS compared to TN. The increase in blood lipids under HS was explained by Rashidi et al. (2010). They pointed out that HS decreased feed intake of broilers compensate their energy requirement by lipolysis of body lipid that it results in increasing the plasma cholesterol and triglyceride levels. On the other hand, Yardibi et al. (2009) and Ajakaiye et al. (2010) reported that serum cholesterol level of laying hens was not significantly affected by HS compared to no heat.

Morever, the TA200, O200, TA200+OSe and $\mathrm{O} 200+\mathrm{OSe}$ diets reduced plasma cholesterol $(\mathrm{P}<0.05)$ and triglyceride $(\mathrm{P}<0.01)$ levels compared to the $\mathrm{NC}$ diet. Sahin et al. (2003) pointed out that vitamin E supplementation reduced plasma cholesterol level in heatstressed Japanese quails. This result concurs with the finding of Rashidi et al. (2010) who showed that the supplementation of vitamin $\mathrm{E}$ and zinc to diets of broiler reared under HS decreased serum cholesterol and triglyceride levels.

The higher levels of stress hormones in circulating system due to HS stimulate lipolysis and increase circulating cholesterol and triglyceride levels. On the other hand, dietary antioxidant sources' supplementation might have been decreased the synthesis of stress hormones such as glucocorticoids in quails under HS. Reduction of glucocorticoids secretion may limit the lipid catabolism and the lipolysis (Hajati et al. 2016). Likewise, Hosseini-Mansoub et al. (2010) found that the antioxidant (vitamin E+zinc) supplementation to diets of broiler chickens reared under thermoneutral and high temperature significantly decreased serum cholesterol and triglyceride levels compared to diet without antioxidant supplementation. Morever, Sujatha et al. (2010) indicated that polyherbal premix supplementation to broiler diets exposed to HS significantly reduced plasma cholesterol. Hosseini-Vashan et al. (2012) reported that dietary turmeric rhizome reduced serum cholesterol concentration in pre- and post-heat stressed chickens. The results of the study of Hajati et al. (2016) indicated that dietary grape seed extract supplementation at $450 \mathrm{mg} / \mathrm{kg}$ diet reduced serum cholesterol and triglyceride levels of broilers under HS. The decrease in serum cholesterol and triglyceride levels may be explained by the reducing effect of herbal extracts on hepatic-3-hydroxy-3-methylglutaryl coenzyme
A reductase that requires for cholesterol synthesis in liver (Ariana et al. 2011).

\section{Conclusions}

It is concluded that dietary supplementation of vitamin $\mathrm{E}$ and oleuropein alone or with organic selenium is necessary to remove the negative effects of heat stress on liver antioxidant status and some plasma parameters of quails.

\section{References}

Ahmed S Kh, Abdul-Abass MH, Al-Hammed SA. 2015. Effect of dietary supplementation of natural and synthetic antioxidants on broilers physiological and productive performance. Egypt. Poultr. Sci., 35 (1): 93-105.

Ajakaiye JJ, Perez-Bello A, Mollineda-Trujillo A. 2010. Impact of vitamins $\mathrm{C}$ and $\mathrm{E}$ dietary supplementation on leukocyte profile of layer hens exposed to high ambient temperature and humidity. Acta Vet. Brno.,79: 377-383.

Akbarian A, Golian A, Kermanshahi H, De Smet S, Michiels J. 2014. Antioxidant enzyme activities, plasma hormone levels and serum metabolites of finishing broiler chickens reared under high ambient temperature and fed lemon and orange peel extracts and curcuma xanthorrhiza essential oil. J Anim. Physiol. and Anim. Nutr., 99 (1): 150-162.

Andreadou I, Iliodromitis EK, Mikros E, Constantinou M, Agalis A, Magiatis P, Skaltsounis L, Kamber E, Tsantili-Kakoulidou A, Kremastinos D TH. 2006. The olive constituent oleuropein exhibits anti-ischemic antioxidative and hypolipidemic effects in anesthetized rabbits. J Nutr.,136: 2213-2219.

AOAC. 2007. Association of Official Analytical Chemists. 18 th. Edition, W.D.C. USA.

Ariana M, Samie A, Edris MA, Jahanian, R. 2011. Effects of powder and extract form of green tea and marigold, and tocopheryl acetate on performance, egg quality and egg yolk cholesterol levels of laying hens in late phase of production. J. Med Plants Res., 5: 2710-2716.

Aruoma OI, Deiana M, Jenner A, Halliwell B, Kaur H, Banni S, Corongiu FP, Dessi MA, Aeschbach R. 1998. Effect of hydroxytyrosol found in extra virgin olive oil on oxidative DNA damage and on low-density lipoprotein oxidation. J Agric. Food Chem., 46: 5181-5187.

Benavente-Garcia O, Castillo J, Lorento J, Ortuno A, Del Rio JA. 2000. Antioxidant activity of phenolics extracted from Olea europaea L. leaves. Food Chem., 68: 457-462.

Duncan DB.1955. Multiple Range Test and Multiple F Tests. Biometrics, 11: 1-42.

El-Damrawy SZ, Khalifah MM, Fares WA. 2013. Dietary olive leaf and antioxidative status in chickens "performance, some physiological traits and immunological responses of mandarah chicks supplemented olive leaves powder in their diets. Egypt. Poult. Sci., 33 (1): 279-287.

Erel O. 2004. A novel automated direct measurement method for total antioxidant capacity using a new generation, more stable ABTS radical cation. Clin Biochem., 37: 277-285.

Erel O. 2005. A new automated colorimetric method for measuring total oxidant status. Clin Biochem.,38: 1103-1111.

Hajati H, Hassanabadi A, Golian A, Nassiri-Moghaddam H, Nassiri MR. 2015. The effect of grape seed extract and vitamin $C$ feed supplementation on some blood parameters and HSP70 gene expression of broiler chickens suffering from chronic heat stress. Italian J Anim Sci., 14 (3): 3273-3281.

Hayes JE, Allen P, Brunton N, O'Grady MN, Kerry JP. 2011. Phenolic composition and in vitro antioxidant capacity of four commercial phytochemical products: olive leaf extract (olea europaea L.) lutein, sesamol and ellagic acid. Food Chem., 126: 948-955. 
Hai BY L, Rong D, Zhang ZY. 2000. The effect of thermal environment on the digestion of broilers. J Anim. Physiol. Anim. Nutr., 83: 57-64.

Hosseini-Mansoub N, Chekani-Azar S, Tehrani AA, Lotfi A, Manesh MK. 2010. Infleunce of dietary vitamin E and zinc on performance, oxidative stability and some blood measures of broiler chickens reared under heat stress $\left(35^{\circ} \mathrm{C}\right)$. J Agribiol., 27 (2): 103-110.

Hosseini-Vashan SJ, Golian A, Yaghobiar A, Zarban A, Afzali N, Esmaeilinasab P. 2012. Antioxidant status, immune system, blood metabolites and carcass characteristic of broiler chickens fed turmeric rhizome powder under heat stress. Afr. J Biotechnol., 11: 16118-16125.

Imik H, Kaynar O, Ozkanlar S, Gumus R, Polat H, Ozkanlar Y. 2013. Effects of vitamin $\mathrm{C}$ and lipoic acid dietary supplementations on metabolic adaptation of broilers to heat stress. Revue Med. Vet., 164 (2): 52-59.

Jang IS, Ko YH, Moon YS, Sohn SH. 2014. Effects of vitamin C or $\mathrm{E}$ on the pro-inflammatory cytokines, heat shock protein 70 and antioxidant status in broiler chicks under summer conditions. Asian Australas. J Anim Sci., 27 (5): 749-756.

Jemai H, Bouaziz M, Fki I, El Fek AI, Sayadi S. 2008. Hypolipidimic and antioxidant activities of oleuropein and its hydrolysis derivative-rich extracts from Chemlali olive leaves. Chem.-Biol. Int.,176: 88-98.

Kara K, Şentürk M, Guclu BK, Sarı̈zkan S, Eren M. 2016. Effect of catechins on fattening performance, meat quality, some antioxidant and blood parameters and fattening costs in Japanese quail (Coturnix coturnix japonica). Br. Poult. Sci., 57 (4): 522-530.

Khan RU. 2011. Antioxidants and poultry semen quality. Worlds Poult. Sci. J., 67: 297-308.

Khan RU, Rahman Z, Javed I, Muhammad F. 2013. Supplementation of vitamins, probiotics and proteins on oxidative stress, enyzmes and hormones in post-moult male broiler breeders. Archiv Tierzucht., 56 (61): 607-616.

Kosecik M, Erel O, Sevinc E, Selek S. 2005. Increased oxidative stress in children exposed to passive smoking. Int. J. Cardiol., 100: 61-64.

Kutlu HR, Forbes JM.1993. Changes in growth and blood parameters in heat-stressed broiler chicks in response to dietary ascorbic acid. Livest. Prod. Sci., 36: 335-350.

Lako J, Trenerry VC, Wahlqwist M, Wattanapenpaiboon N, Sotheeswaran S, Preimer R. 2007. Phytochemical flavonols, carotenoids and the antioxidant properties of a wide selection of Fijian fruit, vegetables and other readily available foods. Food Chem., 101: 1727-1741.

Lee KW, Everts H, Beynen AC. 2004. Essential oils in broiler nutrition. Int. J Poult. Sci. 3: 738-752

NRC. 1994. Nutrient Requirements of Domestic Animals. Nutrient Requirements of Poultry (9th ed). National Academic Press, Washington, D.C., USA.

Rashidi AA, Ivari YG, Khatibjoo A, Vakilia R. 2010. Effects of dietary fat, vitamin $\mathrm{E}$ and zinc on immune response and blood parameters of broiler reared under heat stress. Res. J Poult. Sci., 3(2): 32-38.
Ruiz-Gutierrez V, Dela Puerta R, Catala A. 2001. The effect of tyrosol, hydoxytyrosol and oleuropein on the non-enzymatic lipid peroxidation of rat liver microsomes. Molec. Cell. Biochem., 217: 35-41.

Ryzner M, Takacova J, Cobanova K, Placha I, Venglouska K, Faix S. 2013. Effect of dietary Salvia officinalis essential oil and sodium selenite supplementation on antioxidative status and blood phagocytic activity in broiler chickens. Acta Vet Brno., 82: $43-48$.

Sahin K, Kucuk O. 2001. Effects of vitamin E and selenium on performance, digestibility of nutrients and carcass characteristics of Japanese quails reared under heat stress $\left(34^{0} \mathrm{C}\right)$. J Anim. Physiol. Anim. Nutr., 85 (11-12): 342-348.

Sahin K, Sahin N, Onderci M, Gursu M.F, Issi M. 2003. Vitamin C and $\mathrm{E}$ can alleviate negative effects of heat stress in Japanese quails. Food Agric.Environ.,1 (2): 244-249.

Sahin K, Onderci M, Sahin N, Gursu MF, Khachik F, Kucuk O. 2006. Effects of lycopene supplementation on antioxidant status, oxidative stress, performance and carcass characteristics in heat-stressed Japanese quail. J Therm. Biol., 31 (4): 307-312.

Seyrek K, Yenisey C, Serter M, Kargın Kiral F, Ulutas PA, Bardakcioglu HE. 2004. Effects of dietary vitamin C supplementation on some biochemical parameters of laying Japanese quails exposed to heat stress $\left(34.8^{0} \mathrm{C}\right)$. Revue Med. Vet., 156: 339-342.

Silva S, Gomes L, Leitao F, Coelho AV, Boas LV. 2006. Phenolic compounds and antioxidant activity of olea europaea L. fruits and leaves. Food Sci. Technol. Int., 12 (5): 385-396.

SPSSWIN. 2007. SPSS for Windows 6.1.4. SPSSWIN, Istanbul, Turkey.

Sujatha V, Korde JP, Radtogi SK, Maini S, Ravikanth K, Rekhe DS. 2010. Amelioration of heat stress induced disturbances of the antioxidant defense system in broilers. J Vet. Med. Anim. Health, 2(3): 18-28.

Surai PF, Noble RC, Speake BK. 1996.Tissue-specific differences in antioxidant distribution and susceptibility to lipis peroxidation during development of the chick embryo. Biochim. et Biophysica Acta.,1304: 1-10.

Surai PF. 2002. Selenium. Natural Antioxidant in Avian Nutrition and Reproduction, (Nottingham, Nottingham University Press).

Tatli Seven P, Yilmaz S, Seven I, Cerci IH, Amnan MA, Yilmaz M. 2009. Effect of propolis on selected blood indicators and antioxidant enzyme activities in broilers under heat stress. Acta Vet. Brno.,78: 75-83.

Tawfeek SS, Hosseinia KMA, Youssef IMI. 2014. The effect of dietary supplementation of some antioxidants on performance, oxidative stress and blood parameters in broilers under natural summer conditions. J World's Poult. Res., 4(1): 10-19.

Yardibi H, Oztabak K, Turkay G. 2009. The metabolic effect of vitamin E supplementation to the diets of laying hens. J Anim. Vet. Adv., 8 (5): 912-916.

Zdunczyk Z, Drazbo A, Jankowski J, Juskiewicz J, Czech A, Antoszkiewicz Z. 2013. The effect of different dietary levels of vitamin $E$ and selenium on antioxidant status and immunological markers in serum of laying hens. Polish J Vet. Sci.,16 (2): 333-339. 